\title{
Valuing water in dry land tourism regions
}

\author{
L. Lehmann \\ University of Ballarat, Australia
}

\begin{abstract}
Water, particularly fresh water, is one of the most critical and scarce natural resources. It is well documented that the tourism industry over-uses water resources by at least a factor of two over permanent residents. In some regions of the world, where tourism is a major industry, this can result in water shortages and degradation of water supplies, as well as increased production of waste water.

Water scarcity in some areas has also led to increased interest in water recycling, desalination, improved water storage capabilities and water conservation measures in order to provide greater water security into the future. This paper aims to review and analyse the current literature concerning water management initiatives in the tourism sector and the contrast between water demand and supply for sustainable tourism.

The diverse nature of tourism activities makes the analysis of water uses and impacts quite different to other sectors such as agriculture or manufacturing. In effect tourism is defined on the basis of consumption rather than production and there are many ways of consuming water in tourism.

The aim of this paper is to identify issues associated with water use and tourism in semi-arid or dryland environments and to inform a wider research project that aims to map the uses of water in tourism, to establish a water valuation method that considers the consumptive nature of tourism and to develop a model to guide tourism policy to achieve sustainable water use for tourism enterprises and communities.
\end{abstract}

Keywords: resource use in tourism, sustainable water use, tourism planning, climate change and tourism, tourism marketing, visitor behaviour. 


\section{Introduction}

This paper syntheses the research into the role that water plays in tourism, sustainable water use in tourism, the nature of water and the opportunities for further research into developing a valuation model for water sustainability in dry land tourism.

There is no question that water is a basic necessity for all life on earth. In 2003, the World Tourism Organisation (WTO) [1] recognised that water is also a critical element in tourism. Hadwen et al [2] highlight that tourism, particularly nature-based and ecotourism, relies on a healthy environment with unspoilt nature and landscapes.

Too little or too much water can have a dramatic impact on a destination's basic ability to provide water for food production and hygiene. Changes in water availability can also have a dramatic impact on the environmental and conservation aspects of a destination, particularly in those areas that rely on that environment as an attraction. Water also has significant recreational attributes for activities such as sailing, fishing and golf. In tourism accommodation water is a critical requirement for pools and spas and in the gardens that surround the venue. As a result tourism industry can be a conspicuous consumer of water at all levels.

In a report on the relationship between freshwater and tourism in the Mediterranean, De Stefano [3] discussed the causal relationship between the tourism industry and a range of water issues including; water shortages, the degradation of water supplies and the local environment, as well as increased production of waste water. But water scarcity in some areas has also led to increased interest in water recycling, desalination and improved water storage capabilities in order to provide greater water security into the future. Thus while tourism can lead to problems with water supplies, it also has the potential to generate solutions.

The United Nations Environment Program (UNEP) [4] has estimated that tourists in Spain use as much as 440 litres a day, more than double the average Spanish citizen. While Stefano [5] states that tourist water use per day is between 300 and 850 litres. Narasaiah [6] indicates that in other regions, tourism water consumption is estimated to be as much as six times that of locals.

Beeton et al [7] have highlighted and identified some of the barriers for the tourism industry in developing a culture of sustainable resource management in south eastern Australia. According to Tourism Victoria [8] there are about 100,000 tourism related businesses in the state of Victoria, many of which are small or micro businesses, spread over a large area. This means that the impact of tourism on water resources is not as obvious as it is in other industries such as agriculture and manufacturing, where the water usage appears to be more concentrated. Forsyth [9] discusses the difficulties in tackling the issue of sustainability in tourism because of the broad range of activities that are covered by the 'tourism industry'. Nonetheless, the more scarce water becomes and the greater the competition for supply, the more difficult it will become for tourism enterprises to compete. 


\section{The literature search}

In undertaking a literature search on this topic it has become apparent that research into some aspects of freshwater usage in tourism has been considered in some arid and semi-arid regions, particularly those with well developed tourism attractions and those that have highly defined water volumes, such as small island states.

There has been some interest in sustainable use of water and this is particularly the case in areas where there is likely to be a significant impact on either water quality, water quantity or both. Essex et al [10] have indicated tourism destinations in the Mediterranean, the world's largest tourism playground, have had to start looking at water use very seriously. Island states have also been interested in sustainable water use because of limited supplies.

Both Draper [11] and Cullen et al [12] have discussed examples in Canada and New Zealand respectively where there has been some interest in sustainable water use in tourism. Both cases are not in areas where water supply and quality problems would normally be considered to be a problem. However it has been recognised that the tourism industry places significant pressure on water resources in relatively small communities on a seasonal basis.

In Australia, the interest has really been restricted to Queensland where there is a significant tourism industry with larger scale operations. A recent pilot project implemented by Tourism Victoria [13] and Sustainability Victoria will see eight regional motels participate in a water wise audit and retrofit program.

There has been a considerable amount of interest in recent times in looking at climate change impacts on tourism, although most of that has focussed on carbon emissions rather than changing water regimes. The 2003 Djerba Declaration on Tourism and Climate Change [14] specifically highlighted the importance of water resources in the tourism industry and of its links with climate change. The recent follow up UNWTO Global Summit in Davos [15], also noted the concerns about the future supply of water and the potential impacts of reduced water supplies in some regions.

It was apparent in much of the literature that water was considered in the context of tourism sustainability and as an attraction. However there has been no research that considers water in a more holistic sense and is capable of mapping how water is impacts on tourism and how it can be effectively valued as a critical input.

\section{The role of water in tourism}

In trying to develop an understanding of the role of water in the context of tourism, it has become apparent tourism is literally awash with water. Not only is water ubiquitous by nature in tourism, it plays a range of different roles right across the sector.

In evidence presented at the Climate Change and Tourism Conference [16] held at Djerba in 2003, the inter-relationship between water and tourism in the Great Horn of Africa region was described. Water is required to grow the plants 
that in turn provide food for herbivorous animals and birds that are in turn the prey for the charismatic mega-fauna that are the main attraction for many tourists. Thus water plays an indirect but essential role in attracting tourists to the region. Conversely, the need to develop quality tourism infrastructure is also placing demands on water resources that are often scarce in this dry land region. The very presence of tourists, who use water, both in a consumptive and nonconsumptive way during their stay is a direct use of water in tourism.

\subsection{Consumptive and non-consumptive water in tourism}

In the context of tourism, water can be considered an input for consumption or as an integral part of the environment that is enjoyed but not consumed. The difference between the two uses is that consumed water is either no longer available or is highly contaminated. Figure 1 demonstrates the difference between non-consumed water, which does not remove any water from the total water resource available and consumed water, which does.

\section{Tourism Destination}
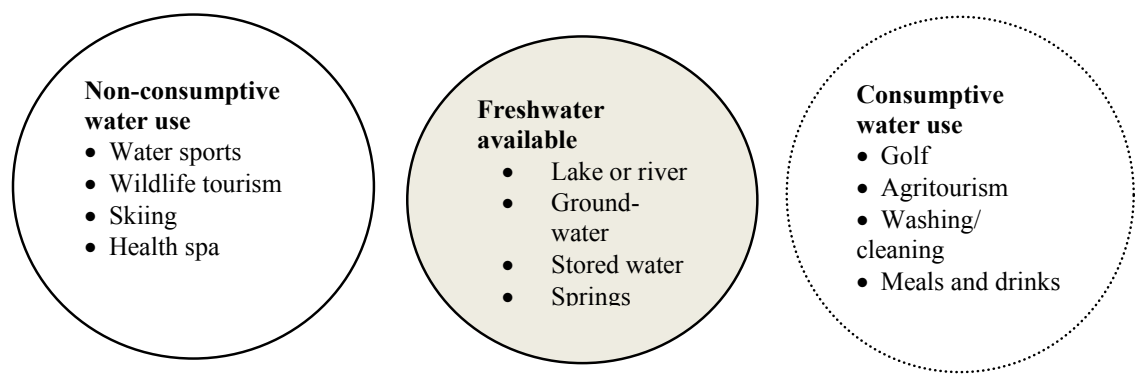

Figure 1: Consumptive and non-consumptive water use.

At a destination level there are regions where water is closely linked to a successful tourism industry through its role as an attraction or as a nonconsumptive use of water. These are areas that use water as a major attractor, including all coastal and beach destinations, alpine destinations, river and lakebased tourism, agri-tourism, tropical destinations and geothermal hot spring areas. Water affects a wide range of environmental resources that can be the main attraction for tourism including wildlife, biodiversity, snow regions and health spas.

In 2007, citing a share in the \$US17.5 billion global market in golf as an incentive, the chairman of the Abu Dhabi, Sheikh Sultan bin Tahnoon Al Nahyan [17] identified golf as a key area for tourism growth for the gulf state. However, golf tourism also has a major consumptive impact on water supply and quality in a number of regions. Narasaiah [18] highlights golf tourism as a large land and water user, golf courses have the ability not only to use large quantity of available water but can also change environmental aspects such as the level of 
the water table and run-off. De Stefano [19] estimates that golf courses require 10,000 and $15,000 \mathrm{~m}^{3}$ of water per hectare each year, which can amount to the equivalent water use of a city with a population of 12,000 people.

In areas where there is a significant level of agritourism, including wine tourism and other farm-based tourism activities, water is also a critical factor to the success of the enterprise. Not only do agricultural and horticultural activities in general consume water in order to produce their product, the addition of tourism activities to the business mix, adds another factor in the water needs of the business.

\subsection{Direct and indirect water use in tourism}

Gössling [20] discusses the direct and indirect ways that the tourism industry uses water resources. Examples of direct water use in tourism include bathing, toilet flushing and washing hands, or any activity that is controlled by an individual tourist. Indirect uses are those that involve the use of water to create an attraction or in the overall running of the tourism business and can include irrigation for gardens, swimming pools, facility cleaning and restaurant purposes. Tourists do not have control of indirect water usage in either the tourism business or destination. In Gössling's Zanzibar case study he identified that the indirect water usage for facilities such as swimming can add significantly to hotel water use, accounting for about $15 \%$ of water demand because of high evaporation rates. In a time where water availability is coming under increasing pressure in many parts of the world, a number of these uses of water in tourism fall well outside the definition of water as a basic life need.

It is relatively easy to look at water in the context of cleaning and washing in the context of a tourism business with average tourist usage ranging from 2 to 7 times that of locals depending on the type of tourist and the destination. Certainly accommodation providers must use water to clean premises, wash linen and provide guests with personal washing facilities, there are also many places that have maintain gardens as well as swimming pools and spas. Gössling [20] highlighted the significantly higher use of water among resort style accommodation compared to guesthouses in his study of sustainable water use in Zanzibar.

\subsection{Spasmodic water use in tourism}

De Stefano [21] discusses the spasmodic water use in many tourism destinations as a result of seasonality or special event tourism. There a numerous destinations that that attract many people to one location for relatively short periods based on specific seasonal activities such as summer beach and water sports or winter snow skiing. Other destinations attract visitors through specific events where large numbers of people are in one location for just a few days, often placing significant pressure on water infrastructure and resources for just that short period. Under these circumstances water usage is often not continuous or consistent; it is highly seasonal and that makes consumption much harder to quantify and water infrastructure needs more difficult to plan for. 


\subsection{Intangible water in tourism}

Another aspect of water is the intangible attraction that people have for water. Water is not only a commodity for use by people; it has elements of sight, sound and feel. There is the sight of a crystal clear swimming pool or a lush garden atmosphere, all present because of water. There is the tinkling sound of a courtyard fountain or the bubbling roar of a spa. There is the spray of water in the face of a water skier or the first sensation of entering the pool on a hot day. Tourism marketing and promotion makes significant use of water in both imagery and words. A recent South Australian tourism brochure for the Limestone Coast region [22] devoted an entire section to water, saying 'Water may be the essence of life, but it's also the backbone of our being, and the basis of boundless Limestone Coast attractions...' There was no evidence that this aspect of water has been considered in the literature thus far.

As a very image conscious industry, there was no evidence in the literature that any analysis of the role or value of water in the success of tourism destinations or enterprises where water was a critical factor in being able to achieve that success. While there has been a lot of work in determining the value of tourism to the economy, the impact of water has not been quantified.

Conversely dramatic changes in water quantity and quality can result in a negative impact on tourism. The recent $2^{\text {nd }}$ International Conference on Climate Change and Tourism in Davos, Switzerland [23], it was recognised that a decrease in water availability can result in drought induced low water levels in lakes and rivers and an increased incidence of wildfires. Even semi-arid areas can experience dramatic increases in water levels as a result of flooding events and this can lead to significant infrastructure damage as well as an increase in some water borne diseases. With the prospect of increasing variability in the quantity and quality of water in many tourism destinations, the sustainable use of fresh water in tourism becomes more critical.

\section{Sustainable use of fresh water in tourism}

The issue of sustainability in tourism has been considered for a number of years now. However sustainability is usually considered in the context of range of tourism inputs such as energy and emissions, transport and material consumption. There are few examples in the literature that consider sustainable use of water at multiple levels. In the case of tourism there are also some distinct linkages. These linkages involve water use at the destination, community, enterprise and individual level. Some of the factors that link water sustainability are supply security, water psychology, education and marketing.

A recent Australian report by Beeton et al [24] into the environmentally sustainable practices of Victorian tourism enterprises recognised that while concerns about sustainability have been growing for the past 20 years and is a primary concern among tourism industry leaders, there were still some significant barriers to achieving practical sustainability at the enterprise level.

At a general community level people have started taking the issue of sustainability seriously and in terms of water use at home very seriously indeed. 
Clarke and Browne [25] showed that considerable effort has been put into a range of programs involving community education programs to encourage behaviour change and accessible technology for home use. In the south eastern Australia state of Victoria, where drought and low water supply has had a significant impact in many areas, Melbourne Water [26] has announced that restrictions on water use have resulted in water consumption levels drop by more than $22 \%$ from the levels of the 1990 s.

Warnken et al [27] highlighted that the 'mind set' of many of tourists can result in quite different behavioural patterns while they are away on holiday. They suggest that the vacation experience is often viewed as time to get away from the rigours of everyday life and indulge oneself. As a result tourists are likely to behave in ways that are less consistent with normal environmental practices they undertake while they are at home.

The role that tourism marketing plays in promoting destinations and activities may also have an impact on the sustainability of the tourism industry. While there has been some research into the relationship between tourism destination and tourist behaviour, there has been no research on what level of influence tourism marketing has on sustainable tourism practices. Tourism Australia [28] has recognised that changing household consumption patterns, a preference for overseas travel in recent years and the stockpiling of annual leave by many Australians has had a significant impact on the way that Australians take holidays. A recent ACNeilsen [29] survey on holiday trends for Australians has also indicated that there has been a growing trend towards short breaks rather than one four week annual holiday break. Recognising this change in the way holidays are taken in Australia, a number of state tourism authorities have also focused a lot of domestic marketing resources on the short break market that is aimed specifically at indulgence tourism; the long weekend away in luxury accommodation is an example. There is limited evidence to indicate that sustainability in the short break or indulgence tourism sector has been considered in the literature.

Measuring sustainability in the tourism industry is also becoming increasingly critical. Beeton et al [30] highlighted the lack of a consistent eco-labelling system across the Australian tourism industry that has both the backing of the industry and the understanding of consumers. Kozak and Nield [31] discussed the limited application of eco-labelling for destinations and proposed that benchmarking could be used to measure the performance of a destination. Most recently, The Helsingborg Statement on Sustainable Tourism [32] recognised the need to measure the impact that tourism has on the environment. If a value is ever going to be placed on water in tourism then the impact that the industry has on water needs to be measured.

\section{The nature of fresh water in tourism}

Water is a fragile resource. In drought we do not have enough and in floods we have too much, and at both extremes we constantly struggle to control it.

De Stefano [33] highlights the problem of water pollution and contamination in the Mediterranean that not only impacts on a tourism destination but may also 
be caused by tourism activity. Ongoing success as a tourism destination relies on the ability to ensure that water infrastructure provides for right quantity of water to be provided at the right quality.

Essex et al [10] discusses the implications of water supply constraints for Butler's tourism destination lifecycle model if water quantity and quality expectations are not met. It concludes in the Mallorca study that water management issues have a significant impact on the rejuvenation stage of the destination in the lifecycle model if there is not some significant restructuring of the local economy that presently relies on conventional tourism activities.

Water resources are affected by many other, competing water uses like agriculture, industry, energy production, transport, mining, recreation and general community uses, so tourism is often just one of many. Becken and Patterson [34] discuss the complicating situation in the case of tourism where the outputs of a number of other industries end up in tourism, thereby making identification of water use even more difficult.

The impact on many tourism destinations of dramatic changes in water quantity and quality cannot be underestimated. However there are also the creeping changes in water supply that gradually impacted on some destinations. This has been particularly evident in semi-arid regions of the world that have endured ongoing drought conditions for a number of years.

\section{Mapping the use of water in tourism}

This paper aims to summarise the research into mapping the various impacts of water in the context of a tourism activity. Table 1 summarises the different types of impact that water has on tourism and categorises the way the water is used.

Analysing these uses will provide some insight into the impact of water on the tourism sector. One of the problems in assessing the impact of water on tourism activities is that often tourism is often not recognised as a sector in its own right, thereby making it more difficult to assess the proportion that is tourism related. In their paper on measuring carbon dioxide emissions from tourism, Becken and Patterson [34] highlight the need to consider tourism on the basis of consumption rather production, with tourism consuming products that are usually accounted for in other industry sectors. There are also a number of impacts that involve secondary industries and therefore could be missed as an impact because there is no direct link. Other impacts are far more intangible and relate to perceptions of water by both the host community and the visitor.

The diverse nature of tourism activities, which encompass elements of a number of other industries, makes the analysis of water impacts completely different from any other sector. In effect tourism is defined on the basis of consumption rather than production and there are many ways of consuming water in tourism. Mapping water consumption in tourism will provide a greater understanding of the overall impact of tourism on water supply and quality. A basic map of water use in a tourism accommodation business in Figure 2 shows some of the relationships between tourism and other sectors. 
Table 1: $\quad$ Classifying water uses in tourism.

\begin{tabular}{|c|c|c|c|c|}
\hline Tourism Level & $\begin{array}{c}\text { Consumptive/ } \\
\text { Non-consumptive }\end{array}$ & $\begin{array}{l}\text { Direct/ } \\
\text { indirect }\end{array}$ & $\begin{array}{l}\text { Spasmodic/ } \\
\text { seasonal }\end{array}$ & $\begin{array}{c}\text { Intangible } \\
\text { factors }\end{array}$ \\
\hline \multicolumn{5}{|l|}{ Destination } \\
\hline Lake/river & both & indirect & sometimes & image \\
\hline Caves & Non-consumptive & indirect & no & \\
\hline Forest & Non-consumptive & indirect & no & image \\
\hline Dam/water storage & consumptive & indirect & no & \\
\hline Hot springs & Non-consumptive & indirect & no & image \\
\hline Snow & Non-consumptive & indirect & yes & image \\
\hline $\begin{array}{l}\text { Attraction- } \\
\text { gardens }\end{array}$ & consumptive & indirect & no & \\
\hline Waste management & consumptive & indirect & sometimes & \\
\hline Biodiversity/wildlife & Non-consumptive & indirect & no & Image/sound \\
\hline Agritourism & Consumptive & indirect & yes & image \\
\hline Marketing & Non-consumptive & indirect & no & \\
\hline Golf & Consumptive & indirect & sometimes & \\
\hline \multicolumn{5}{|l|}{ Enterprise } \\
\hline Swimming pool & Consumptive & indirect & yes & image \\
\hline Spa & Consumptive & indirect & no & image \\
\hline Garden & Consumptive & indirect & sometimes & Image/sound \\
\hline Waste management & Consumptive & indirect & sometimes & \\
\hline Cleaning & Consumptive & indirect & no & \\
\hline Food supply & Consumptive & indirect & no & \\
\hline Marketing & Non-consumptive & indirect & no & \\
\hline \multicolumn{5}{|l|}{ Activities } \\
\hline Hunting & Non-consumptive & indirect & yes & Image \\
\hline Boating & Non-consumptive & indirect & Yes & Image \\
\hline Fishing & Non-consumptive & indirect & Yes & Image \\
\hline Swimming & Non-consumptive & indirect & Yes & Image \\
\hline Bird watching & Non-consumptive & indirect & Yes & Image/sound \\
\hline \multicolumn{5}{|l|}{ Tourist } \\
\hline Personal hygiene & Consumptive & Direct & No & \\
\hline Food \& drink & Consumptive & Direct & No & \\
\hline Travel & Non-consumptive & Direct & no & \\
\hline
\end{tabular}

In considering the nature of water usage in the tourism sector in dry land areas, there are a number of issues that could be considered in the context of this research. The decisions made by tourists who visit (or those who choose not to visit) because of real or perceived water supply problems and how this has impacted on the tourism industry. The role of tourism marketing and promotion and the media will also have a significant impact on how tourists react to the role of water in a particular tourism region.

\section{An appropriate value for water}

It was Benjamin Franklin who said 'when the well runs dry, we'll know the value of water'. Having established how the tourism sector uses water, it is then necessary to consider how to value that water. The problem with working out how to value water in tourism is that the real value of water is neither its price nor cost. 
While there has been a considerable body of research on valuing water in a variety of contexts, there has been very little research into how water should be valued in tourism. In a presentation on the value of water, Linsky [35] suggests that the real value of water should be related to how it is used. This would mean that water used to sustain human life has the highest value. Water that is used to maintain the environment would have a different value to water used to fill a swimming pool. Seasonality will also have an impact on water value with a high value being placed on water needed for fire suppression during the summer fire season.

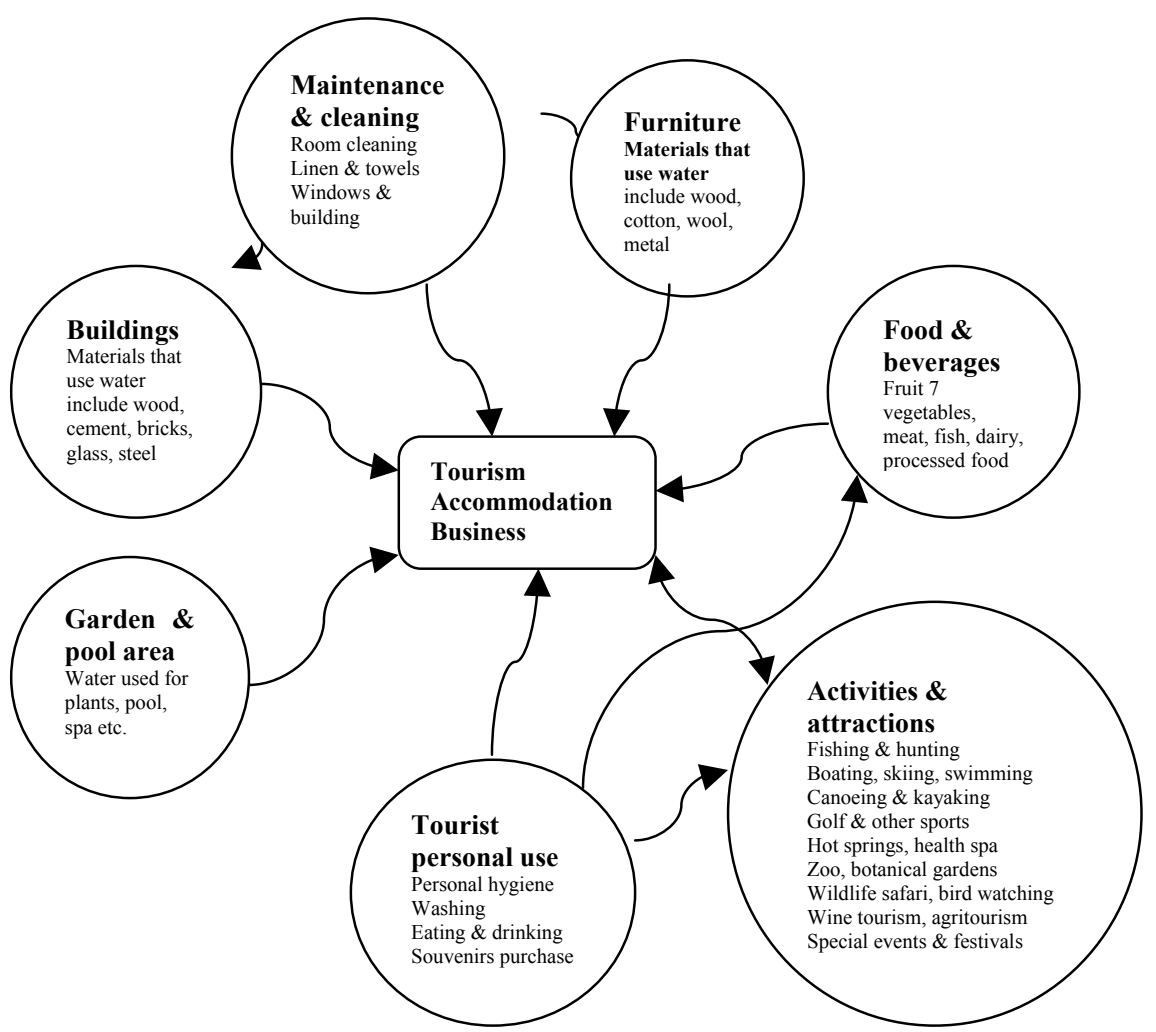

Figure 2: $\quad$ Basic mapping of water use at a tourism accommodation business.

There are a number of issues that need to be considered in order to develop an appropriate model for valuing water in tourism. Table 2 summarises the range of valuation methods that have been identified for consideration so far in this research to develop a tourism water valuation model.

Another factor that will add to the complexity of valuing water in tourism is the need to identify the percentage of water that relates to the tourism use compared to other uses. In areas where tourism is the most significant economic driver then the calculation will be relatively simple. However in mixed 
economies where tourism is one of several competing water users, an assessment of the level of water use will need to be made.

The approach to measurement of carbon dioxide emissions in tourism outlined by Becken and Patterson [34] in undertaking a bottom up analysis at industry level and combining it with top-down analysis using integrated economic-environmental accounting will be assessed to see if it can also be applied to water.

Table 2: $\quad$ Valuation methods for water in tourism.

\begin{tabular}{|c|c|c|}
\hline $\begin{array}{l}\text { Valuation } \\
\text { Method }\end{array}$ & $\begin{array}{l}\text { Impact on tourism water } \\
\text { valuation }\end{array}$ & Variables to be included \\
\hline \multicolumn{3}{|l|}{$\begin{array}{l}\text { Revealed } \\
\text { willingness to pay }\end{array}$} \\
\hline $\begin{array}{l}\text { Market Price } \\
\text { method [36] }\end{array}$ & $\begin{array}{l}\text { Estimates economic values for } \\
\text { products or services that are } \\
\text { bought and sold in commercial } \\
\text { markets }\end{array}$ & $\begin{array}{l}\text { Economic, environmental, } \\
\text { recreational, health, } \\
\text { cultural }\end{array}$ \\
\hline $\begin{array}{l}\text { Productivity } \\
\text { method [36] }\end{array}$ & $\begin{array}{l}\text { Estimates economic values for } \\
\text { products and services that } \\
\text { contribute to production of } \\
\text { commercially marketed goods. }\end{array}$ & Economic, environmental \\
\hline $\begin{array}{l}\text { Hedonic pricing } \\
{[38]}\end{array}$ & $\begin{array}{l}\text { Estimates economic values for } \\
\text { services that directly affect the } \\
\text { market price of some other good. }\end{array}$ & $\begin{array}{l}\text { Economic, environmental, } \\
\text { health, water quality }\end{array}$ \\
\hline $\begin{array}{l}\text { Travel cost method } \\
\text { [39] }\end{array}$ & $\begin{array}{l}\text { Value is reflected in how much } \\
\text { people are prepared to pay to } \\
\text { travel to a place. }\end{array}$ & Economic, recreational \\
\hline \multicolumn{3}{|l|}{$\begin{array}{l}\text { Imputed } \\
\text { willingness to pay }\end{array}$} \\
\hline $\begin{array}{l}\text { Substitute cost } \\
{[36]}\end{array}$ & $\begin{array}{l}\text { Estimate of cost to provide a } \\
\text { substitute }\end{array}$ & $\begin{array}{l}\text { Economic, environmental, } \\
\text { recreational, health }\end{array}$ \\
\hline \multicolumn{3}{|l|}{$\begin{array}{l}\text { Expressed } \\
\text { willingness to pay }\end{array}$} \\
\hline $\begin{array}{l}\text { Contingent value } \\
\text { method [36] }\end{array}$ & $\begin{array}{l}\text { Estimates the value identified by } \\
\text { people on their willingness to pay }\end{array}$ & $\begin{array}{l}\text { Economic, environmental, } \\
\text { recreational, health, quality }\end{array}$ \\
\hline
\end{tabular}

The aim of this research is to identify appropriate case studies that can be undertaken to assess how appropriate these water valuation methods are for tourism and what combination of valuation methods could be used to develop a tourism water valuation model.

\section{Future directions for research}

While it is clear that there is a good level of understanding the issues relating to water infrastructure needs in dry land tourism areas, the potential impacts of climate change on water supply, the way that tourists make decisions about holiday destinations and the behaviour of tourists when they are on holiday, there 
has been little work done on developing a holistic model of the usage and value of water in dry land tourism regions.

By completing the mapping of both the types of water usage and valuation methods in tourism, it will then be possible to manage and develop tourism destinations and enterprises in a changing environment. Giving value to tourism water will also assist the industry in communicating water usage messages and how consumers can change their water usage expectations while on holiday.

\section{References}

[1] WTO (2003). Climate Change and Tourism. Djerba, Climate Change and Tourism, Djerba, Tunisia, World Tourism Organization, p. 43

[2] Hadwen, W, Arthington, A., Boon, P., Lepesteur, M \& McComb, A, Rivers, Streams, Lakes and Estuaries, hot spots for cool recreation and tourism in Australia, CRC for Sustainable Tourism Pty Ltd, p. 1, 2006.

[3] De Stefano, L, Freshwater and Tourism in the Mediterranean, WWF Mediterranean Programme, Rome, pp. 5-16, 2004.

[4] Tourism's three main impact areas; United Nations Environment Program.

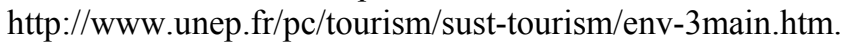

[5] De Stefano, L, Freshwater and Tourism in the Mediterranean, WWF Mediterranean Programme, Rome, p. 4, 2004.

[6] Narasaiah, M.L. Water and Sustainable Tourism, Discovery Publishing House, New Delhi, pp. 58-60, 2005.

[7] Beeton, S., Bergin-Seers, S. \& Lee, C., Environmentally Sustainable Practices of Victorian Tourism Enterprises, Sustainable Tourism CRC, Gold Coast, 2007.

[8] Sustainability in Tourism Strategy; Tourism Victoria. http:/www.tourismexcellence.com.au/module7/index.php

[9] Forsyth, T., Environmental Responsibility and Business Regulation: The Case of Sustainable Tourism. The Geographical Journal, Vol. 163 (Nov., 1997), pp. 270-280

[10] Essex, S., Kent, M. \& Newnham, R., Tourism Development in Mallorca: Is Water Supply a Constraint? Journal of Sustainable Tourism, 12/1, pp 4-28, 2004

[11] Draper, D., Touristic Development and Water Sustainability in Banff and Canmore, Alberta, Canada. Journal of Sustainable Tourism, 5/3, pp 183 212, 1997.

[12] Cullen, R., Dakers, A. \& Meyer-Hubbert, G., Tourism, Water, Wastewater and Waste Services in Small Towns, Tourism Recreation Research and Education Centre, 2004

[13] Sustainability in Tourism Program, Tourism Victoria. http://www.tourismexcellence.com.au/module7/index.php?page=supportpr ograms

[14] Djerba Declaration on Tourism and Climate Change, UNWTO, 2003

[15] Scott, D., Amelung, B., Becken, S., Ceron, J.P., Dubois, G., Gössling, S., Peeters, P. \&Simpson, M.C., Climate Change and Tourism: Responding to 
Global Challenges, United Nations Environment Program, United Nations World Tourism Association, World Meteorological Organisation, pp. 5-6, 2007

[16] World Tourism Association, Round Table No1 - Tourism and water resources, Proceedings of the $1^{\text {st }}$ International Conference on Climate Change and Tourism, pp. 43-45, 2003

[17] ArabianBusiness.com, Abu Dhabi targets golf tourism, Monday, 01 January 2007. http://www.arabianbusiness.com/6099-abu-dhabi-targets-golftourism? $\ln =\mathrm{en}$

[18] Narasaiah, M.L. Water and Sustainable Tourism, Discovery Publishing House, New Delhi, pp. 59-60, 2005.

[19] De Stefano, L, Freshwater and Tourism in the Mediterranean, WWF Mediterranean Programme, Rome, pp. 10-11, 2004.

[20] Gössling, S. The consequences of tourism for sustainable water use on a tropical island: Zanzibar, Tanzania. Journal of Environmental Management 61, pp.179-191, 2001.

[21] De Stefano, L, Freshwater and Tourism in the Mediterranean, WWF Mediterranean Programme, Rome, p. 10, 2004.

[22] South Australian Tourism Corporation, South Australia Limestone Coast, pp.18-19, 2008

[23] Scott, D., Amelung, B., Becken, S., Ceron, J.P., Dubois, G., Gössling, S., Peeters, P. \&Simpson, M.C., Climate Change and Tourism: Responding to Global Challenges, United Nations Environment Program, United Nations World Tourism Association, World Meteorological Organisation, pp. 4-7, 2007

[24] Beeton, S., Bergin-Seers, S. \& Lee, C., Environmentally Sustainable Practices of Victorian Tourism Enterprises, Sustainable Tourism CRC, Gold Coast, p. 1, 2007.

[25] Clarke, J.M. \& Brown, R.R., Understanding the factors that influence domestic water consumption within Melbourne. Australian Journal of Water Resources, 10(3), pp. 261-267

[26] Melbourne Water http://www.melbournewater.com.au/content/water/water_storages/water_st orages.asp?bhcp=1

[27] Warnken, J., Bradley, M. \& Guilding, C., Exploring methods and practicalities of conducting sector-wide energy consumption accounting in the tourist accommodation industry. Ecological Economics 48, pp. 125141,2004

[28] Stimulating Domestic Tourism, 2007-2008, Tourism Australia. http://www.tourism.australia.com/content/Australia/2007/stimulating_dome stic_tourism_2007-08.pdf

[29] Holiday and travel trends, ACNeilsen Pubic Enterprise News, 2008. http://www.acnielsen.com.au/enterprise/issue4/service.html

[30] Beeton, S., Bergin-Seers, S. \& Lee, C., Environmentally Sustainable Practices of Victorian Tourism Enterprises, Sustainable Tourism CRC, Gold Coast, pp. 5-6, 13-14, 2007. 
[31] Kozak, M \& Nield, K., The Role of Quality and Eco-labelling Systems in Destination Benchmarking. Journal of Sustainable Tourism, 12,2 pp.138148,2004

[32] Gössling, S., The Helsingborg Statement on Sustainable Tourism. Journal of Sustainable Tourism, 16,1 pp.122-124, 2008

[33] De Stefano, L, Freshwater and Tourism in the Mediterranean, WWF Mediterranean Programme, Rome, pp. 10-15, 2004.

[34] Becken, S. \& Patterson, M., Measuring National carbon Dioxide Emissions from Tourism as a Key Step towards Achieving Sustainable Tourism. Journal of Sustainable Tourism, 14, 4 pp.323-337, 2008

[35] Linsky, R.B., The Value of Water: Education and Understanding. Australian Water Association Inaugural Education Conference, 2004.

[36] King, D. \& Mazzotta, M, Ecosystem, Valuation http://www.ecosystem valuation.org

[37] Young, R.A. Determining the Economic Value of Water Concepts and Methods, Resources for the Future, Washington, pp. 47, 177-182, 2005

[38] Young, R.A. Determining the Economic Value of Water Concepts and Methods, Resources for the Future, Washington, pp. 47, 120-128, 2005

[39] King, D. \& Mazzotta, M, Ecosystem, Valuation http://www.ecosystem valuation.org/travel_costs.htm 